\title{
OESTROGEN METABOLISM IN SHEEP MYOMETRIUM
}

\author{
GADIJA ROSSIER AND C. G. PIERREPOINT \\ Tenovus Institute for Cancer Research, Heath, Cardiff CF4 $4 X X$
}

(Received 29th March 1973)

\begin{abstract}
Summary. Ovine myometrium obtained at 127 and 119 days of gestation was incubated in vitro with $\left[4-{ }^{14} \mathrm{C}\right]$ oestrone and $\left[6,7-{ }^{3} \mathrm{H}_{2}\right]$ oestradiol$17 \alpha$, and $\left[4-{ }^{14} \mathrm{C}\right]$ oestrone and $\left[6,7-{ }^{3} \mathrm{H}_{2}\right]$ oestrone-3-sulphate, respectively. It was considered significant that oestrone was converted mainly to the much more potent oestradiol- $17 \beta$ with very little transformation to the $17 \alpha$-epimer. A high level of sulphatase activity was demonstrated by the formation of oestrone and oestradiol-17 $\beta$ from oestrone sulphate whereas the isolation of small amounts of oestrogen-3-sulphates also provided evidence of sulphotransferase enzyme activity in this tissue.

These findings are discussed in connection with steroid metabolism by the sheep fetus and placenta and the possible significance of the metabolites isolated with regard to hormonal action in the myometrium.
\end{abstract}

\section{INTRODUGTION}

A great deal of experimental investigation has been directed to the subject of the hormonal control of the uterus during pregnancy and parturition. The importance of oestrogens in this respect and in the adaptation to viviparity has been widely discussed (Deanesly, 1966; Ryan, 1969).

The relative quiescence of the myometrium until term and the rapid onset of activity at parturition appears to be controlled by a critical balance of oestrogens and progesterone (Csapo, 1961, 1969; Schofield, 1964). Castration experiments have shown that the placenta is capable of taking over the maintenance of pregnancy from the maternal ovaries at particular stages in most of the higher mammals and that the timing of this function is species-specific (Ryan, 1969). The steroid biosynthetic capacity of the placenta has been investigated and it is now well established that it can function as a source of oestrogens and progesterone for a number of species including the sheep (Ryan, 1969; Pierrepoint, Anderson, Griffiths \& Turnbull, 1970a, b). Controversy persists, however, as to the exact conformation of the steroids at the time they exert their hormonal effects in the myometrium. It has not yet been clearly established whether biochemical transformation within the myometrium of circulating hormones is a necessary prerequisite for their action, as would appear to be the case for androgens within male target organs (Williams-Ashman \& Reddi, 1971). There are few reports in the literature on steroid metabolism in the myometrium (Wiest, 1963; Sweat, Bryson \& Young, 1967; Wichmann, 1967) and the present communication reports investigations on the presence and activity of steroidmetabolizing enzymes in the myometrium of the pregnant ewe. No previous information has been available for this species. 


\section{MATERIALS AND METHODS}

Uterine tissue was obtained by Caesarean hysterectomy from two sheep at 119 and 127 days of gestation, respectively. The myometrium was separated from the endometrium in each case and $4 \mathrm{~g}$ chopped tissue were incubated in $24 \mathrm{ml}$ Krebs-Ringer bicarbonate-glucose solution $(\mathrm{pH} 7.4)$ at $39.5^{\circ} \mathrm{C}$ in an atmosphere of $95 \% \mathrm{O}_{2}: 5 \% \mathrm{CO}_{2}$.

The incubation vessels contained the following isotopically labelled substrates: Experiment (a) 127-day tissue: $2 \mu \mathrm{Ci}\left[{ }^{4-14} \mathrm{C}\right]$ oestrone $(29.5 \mathrm{Ci} / \mathrm{mol}), 20 \mu \mathrm{Ci}$ [6,7- $\left.{ }^{3} \mathrm{H}_{2}\right]$ oestradiol-17 $(33 \mathrm{Ci} / \mathrm{mmol})$; Experiment (b) 119-day tissue: $2 \mu \mathrm{Ci}$ $\left[4-{ }^{14} \mathrm{C}\right]$ oestrone $(51 \mathrm{Ci} / \mathrm{mol}), 15 \mu \mathrm{Ci}\left[6,7-{ }^{3} \mathrm{H}_{2}\right]$ oestrone-3-sulphate $(470 \mathrm{Ci} / \mathrm{mol})$; Experiment (c) oestrone sulphate is notoriously hydrophilic and its stability under the conditions of incubation employed was examined by incubating $1 \mu \mathrm{Ci}\left[6,7-{ }^{3} \mathrm{H}_{2}\right]$ oestrone-3-sulphate $(470 \mathrm{Ci} / \mathrm{mol})$ in the absence of tissue.

In each case, the reaction was terminated after $2 \mathrm{hr}$ by the addition of $80 \mathrm{ml}$ acetone and the mixtures were refrigerated at $-15^{\circ} \mathrm{C}$. The non-radioactive carrier steroids ( $500 \mu \mathrm{g}$ of each), added to the incubation mixtures before homogenization and extraction, are listed below.

To Exp. (a): oestrone, oestradiol-17 $\alpha$, oestradiol-17 $\beta$, oestriol, $1,3,5(10)$ -

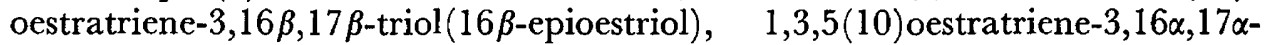
triol (17 $\alpha$-epioestriol), and 1,3,5(10)oestratriene-3,16 $\beta, 17 \alpha$-triol $(16 \beta, 17 \alpha$-epioestriol).

The following conjugates ( $500 \mu \mathrm{g}$ of each) were added to the aqueous fraction: oestrone-3-sulphate, oestradiol-17 $\beta$-3-sulphate, oestradiol-17 $\beta$-17-sulphate and oestradiol-17 $\beta$-disulphate. Sulphates of oestradiol-17 $\alpha$ were not available at the time of this investigation and the possible formation of these compounds was examined by the addition of $200 \mu \mathrm{g}$ of the free steroid to the aqueous fractions after hydrolysis.

To Exp. (b) : oestrone, oestradiol-17 $\alpha$, oestradiol-17 $\beta$, oestrone-3-sulphate, oestradiol-17 $\beta$-3-sulphate, oestradiol-17 $\beta$-17-sulphate, oestradiol-17 $\beta$-disulphate and oestradiol-17 $\alpha-3$-sulphate. In order to investigate the formation of oestradiol-17 $\alpha$-17-sulphate and oestradiol-17 $\alpha$-disulphate, the free steroid was added at the equivalent stage of the selective hydrolysis procedure (see below).

The incubation mixtures were homogenized and the steroids and their conjugates were extracted by methods described previously (Pierrepoint, Anderson, Harvey, Turnbull \& Griffiths, 1972). Purification of the steroids and their derivatives was achieved by chromatography on thin layers of Merck Silica Gel $\mathrm{HF}_{254 / 366}$. Authentic standards were chromatographed adjacent to the samples and both were located using light at either 240 or $350 \mathrm{~nm}$. Solvent systems (proportions by volume) employed during the investigations were I. Chloroform:acetone (37:3); II. Hexane: ethyl acetate (3:2); III. Cyclohexane: ethyl acetate $(3: 1)$; IV. Benzene: ethyl acetate $(9: 1)$; V. Chloroform: acetone (3:1); VI. Tert. butanol:ethyl acetate:5 $\mathrm{N}$-ammonium hydroxide $(41: 50: 20)$.

Steroid sulphates were separated from any residual unconjugated steroids remaining in the aqueous fractions by chromatographing on silica gel in solvent system VI. The phenolic steroid sulphates were eluted and subjected to selective 
hydrolysis by the addition of $1.5 \mathrm{mg}$ Helicase (L'Industrie Biol. France, S.A., Gennevilliers, France) in $1.0 \mathrm{ml} 0.1 \mathrm{~m}$-acetate buffer $/ 200 \mu \mathrm{g}$ steroid sulphate and incubating at $37^{\circ} \mathrm{C}$ for $18 \mathrm{hr}$. This enzyme hydrolyses steroid 3-sulphates but is without effect on steroid 17-sulphates. The resultant free steroids were extracted with ethyl acetate. The remaining conjugate residues (17-sulphates) were then hydrolysed by acid solvolysis according to the method of Burstein \& Lieberman (1958). It was at this stage that the oestrogens not available as sulphates were added in the free form to the requisite oestradiol fraction.

Radioactivity was measured using a Nuclear Chicago liquid scintillation spectrometer Mark 2, whilst labelled steroids on chromatograms were detected using a radiochromatogram scanner (Berthold Aerograph Model 600).

Steroids and their derivatives were measured by gas-liquid chromatography using $1 \%$ or $2 \%$-SE30 on Gas-chrome Q. Chromatographic behaviour of a steroid and two derivatives and the observation that the three specific activities varied by less than $10 \%$ was taken as evidence of radiochemical purity.

\section{RESULTS}

The distribution of radioactivity in the fractions isolated from Experiments (a) and (b) are shown in Table 1 and from Exp. (c) in Table 2. Table 3 shows the metabolites isolated from the incubation studies with $\left[4-{ }^{14} \mathrm{C}\right]$ oestrone and $\left[6,7-{ }^{3} \mathrm{H}_{2}\right]$ oestradiol- $17 \alpha$ (Exp. a) and $\left[4-{ }^{14} \mathrm{C}\right]$ oestrone and $\left[6,7-{ }^{3} \mathrm{H}_{2}\right]$ oestrone

Table 1. Distribution of radioactivity in various solvent fractions of incubated sheep myometrium

\begin{tabular}{|c|c|c|c|c|}
\hline \multirow{2}{*}{ Solvent fraction } & \multicolumn{2}{|c|}{$\begin{array}{c}\text { Experiment }(a) \\
127 \text { days gestation }\end{array}$} & \multicolumn{2}{|c|}{$\begin{array}{c}\text { Experiment }(b) \\
119 \text { days gestation }\end{array}$} \\
\hline & $\begin{array}{c}\text { From } \\
{\left[4-{ }^{14} C\right]-} \\
\text { oestrone }\end{array}$ & $\begin{array}{c}\text { From }\left[6,7-{ }^{3} \mathrm{H}_{2}\right]- \\
\text { oestradiol-17 }\end{array}$ & $\begin{array}{c}\text { From } \\
{\left[4-{ }^{14} C\right]-} \\
\text { oestrone }\end{array}$ & $\begin{array}{c}\text { From }\left[6,7-{ }^{3} \mathrm{H}_{2}\right]- \\
\text { oestrone-3- } \\
\text { sulphate }\end{array}$ \\
\hline Total free steroid & $78 \cdot 7$ & 71.5 & $89 \cdot 1$ & $92 \cdot 1$ \\
\hline $\begin{array}{l}\text { Aqueous residue } \\
\text { (conjugates) }\end{array}$ & 3.92 & 4.04 & $1 \cdot 18$ & $11 \cdot 3$ \\
\hline $\begin{array}{l}\text { Petroleum ether } \\
\text { (non-polar lipids) }\end{array}$ & $1 \cdot 30$ & 0.63 & 0.56 & 0.49 \\
\hline
\end{tabular}

Figures are percentages of incubated radioactivity.

Table 2. Distribution of radioactivity in the various solvent fractions after incubation with $1 \mu \mathrm{Ci}\left[6,7-{ }^{3} \mathrm{H}_{2}\right]$ oestrone-3-sulphate in the absence of sheep myometrial tissue

\begin{tabular}{l|c}
\hline \multicolumn{1}{c|}{ Fraction isolated } & $\begin{array}{c}\text { Percentage of initial } \\
\text { radioactivity }\end{array}$ \\
\cline { 2 - 2 } Total free steroid & 3.68 \\
Aqueous residue (conjugates) & $92 \cdot 3$ \\
Petroleum ether & 0.69 \\
\hline
\end{tabular}




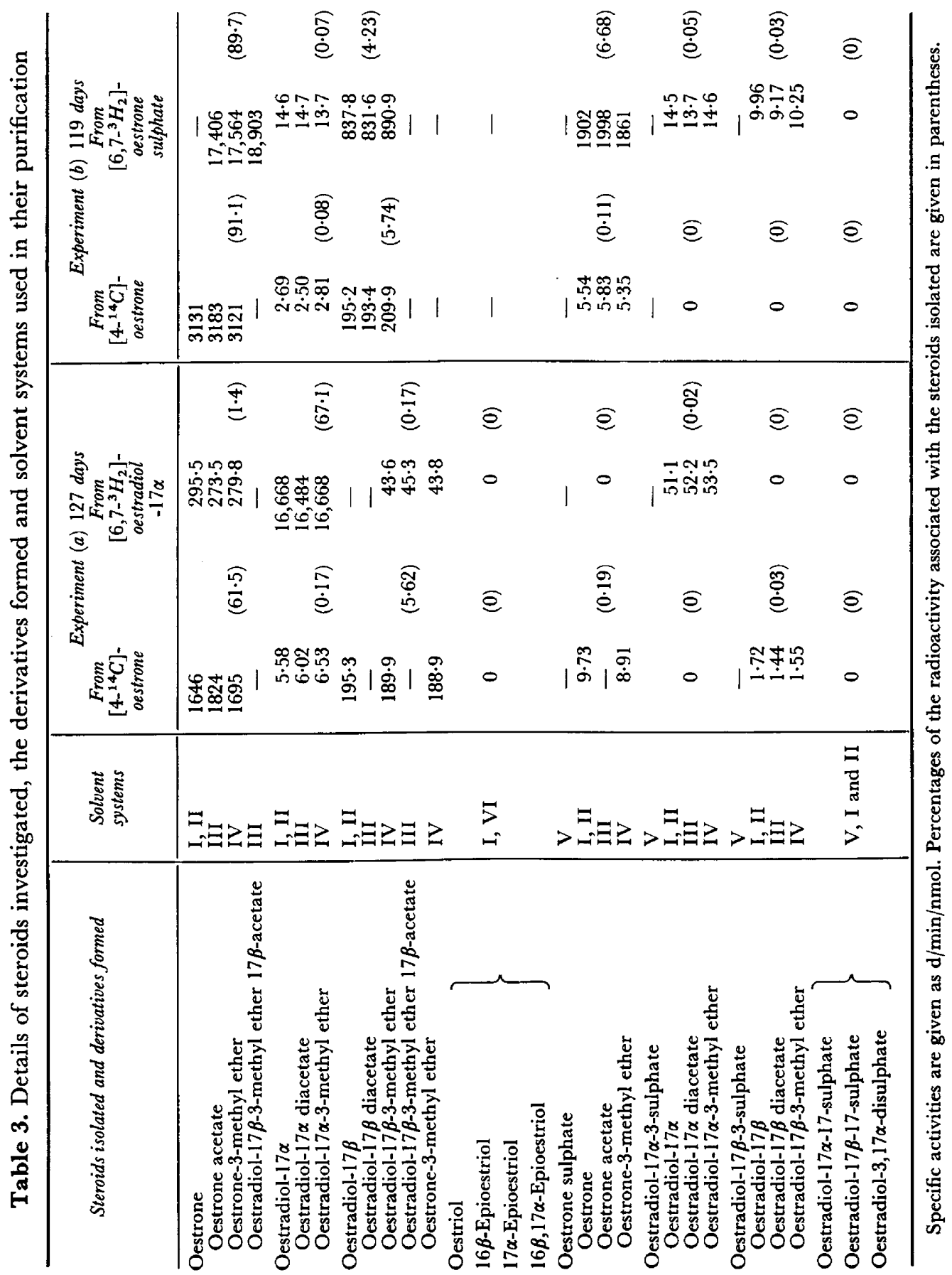


sulphate (Exp. b). A similar degree of metabolism was achieved of both oestrone and oestradiol- $17 \alpha$ by the 127 -day myometrial tissue in that $38.5 \%$ and $32.9 \%$ of each substrate was transformed to other products. Not all of the radioactivity was accounted for although it is noteworthy that oestradiol-17 $\beta$, a potent oestrogen, was the major metabolite of incubated oestrone. This was also the case in the second incubation with tissue taken at 119 days of pregnancy (Exp. b).

The isolation of isotopically-labelled oestrone-sulphate, oestradiol-17 $\beta$-3sulphate and oestradiol-17 $\alpha$-3-sulphate from Exp. (a) provides evidence for the presence in this tissue of phenolic-3-sulphokinases.

Particularly noteworthy was the extensive hydrolysis of oestrone sulphate as indicated by the high level of radioactivity from this substrate eventually isolated in the free steroid fraction (Table 1). The chief metabolites were oestrone $(89.7 \%)$ and oestradiol- $17 \beta(4.23 \%)$. There was little oestradiol- $17 \alpha$ made from this substrate.

The extensive metabolism of oestrone sulphate was further indicated by the very low recovery of the unchanged substrate $(\sim 7 \%)$.

The results listed in Table 2 show that the incubation and extraction procedures adopted during the investigation had little effect on the stability of the substrate, $\left[6,7-{ }^{3} \mathrm{H}_{2}\right]$ oestrone sulphate, and that the hydrolysis observed in the tissue experiments was due to myometrial sulphatase enzyme activity.

Small yields of oestradiol-17 $\alpha$-3-sulphate and oestradiol-17 $\beta$-3-sulphate were obtained from oestrone sulphate, which suggests that this steroid conjugate can act as substrate for $17 \alpha$ - and $17 \beta$-hydroxysteroid dehydrogenases.

Oestriol was not formed in any of the studies.

\section{DISCUSSION}

It has been reported that the changes that take place in the myometrium during pregnancy can be reproduced in the non-pregnant animal by the administration of oestradiol-17 $\beta$ (Segal \& Scher, 1967; Hamilton, 1971). This steroid stimulates the synthesis of the contractile protein, actomyosin (Needham \& Cawkwell, 1957), and also reduces the threshold of stimulation of the myometrial cell to oxytocin (Fitzpatrick, 1960; Kuriyama, 1961; Knifton, 1967; Brinsfield, 1968).

The site of formation of oestrogens in the later stages of pregnancy in higher mammals is the placenta, compensating for waning ovarian function (see Ryan, 1969). Aromatization of $\mathrm{C}_{19}$-steroids is an active process in the sheep placenta (Pierrepoint et al., 1970a; Pierrepoint, Anderson, Turnbull \& Griffiths, 1973) and the appearance of isotopically-labelled oestrogens in the myometrium after the perfusion of the placenta in situ with a labelled androgen has been demonstrated (G. Rossier \& C. G. Pierrepoint, unpublished data).

The ability of the sheep placenta to produce oestradiol-17 $\beta$ is not marked, however, when compared with that for oestrone and oestrone sulphate (Pierrepoint et al., 1972; Harvey, Pierrepoint, Anderson, Turnbull \& Griffiths, 1972). It was the purpose of these investigations therefore to examine the further metabolism of these non-potent oestrogens in the myometrium with regard to the participation of this target organ in hormone action. 
The results show a highly significant phenolic steroid transformation by the sheep myometrium, providing evidence for the presence of $17 \alpha$-and $17 \beta$-hydroxysteroid dehydrogenases, specific sulphokinases and high sulphatase enzyme activity. Oestradiol-17 $\beta$ was the major metabolite of oestrone metabolism in both studies with this substrate whilst oestrone sulphate was virtually completely hydrolysed to the free form and then further converted to the -diol. Oestradiol$17 \alpha$ was not formed to a significant extent from the other substrates. Phenolic steroid $17 \alpha-$-reductase in the placenta is likewise not an active enzyme when compared to the equivalent enzyme acting on the neutral steroids (Pierrepoint et al., 1970a, 1973) and the high levels of oestradiol-17 $\alpha$ in maternal urine must be attributable to metabolism elsewhere in the mother.

Whether oestrone and its sulphate have a function in the myometrium of this species cannot at present be answered. Low, but significant, levels of sulphokinase activities were demonstrated and the oestrogen sulphates formed may promote protein synthesis as has been described in the rat (Brooks, Leithauser, De Loecher \& De Wever, 1969). Sulphatase activity was certainly far more prominent, promoting the formation of free oestrogens.

Thus, the direction of myometrial metabolism is towards the potent oestrogen, oestradiol- $17 \beta$, and it is pertinent to note that two binding macromolecules have been isolated from the cytosol fraction of pregnant sheep myometrium sedimenting in the $4 \mathrm{~S}$ and $8 \mathrm{~S}$ regions, respectively (Rossier, Pierrepoint, Wilson \& Griffiths, 1972), which show greater affinity for this steroid than for oestrone or oestradiol-17 $\alpha$.

These results support the concept that a target organ participates in hormone action by transforming the steroids presented to it and then preferentially binding the active species formed.

It appears that the sheep placenta provides reservoirs of both oestrone and oestrone sulphate which are available to the myometrium where they are further converted to the potent and active oestrogen, oestradiol-17 $\beta$. The myometrium is not a tissue specialized for active synthesis of oestrogens (Rossier \& Pierrepoint, 1974), but its own peculiar metabolic activity does determine the final structure of the oestrogen which binds within the myometrial cell to influence the contractile mechanism of the organ throughout pregnancy and at parturition. The levels achieved will depend on placental production of the precursors and, equally important, the activity of hydrolysing and $17 \beta$ hydroxysteroid dehydrogenase enzymes in the myometrium itself.

\section{ACKNOWLEDGMENTS}

The authors wish to thank the Wellcome Trust and the Tenovus Organisation for generous financial support and laboratory facilities. The oestradiol-17 $\alpha-3-$ sulphate was kindly supplied by Dr Gilbert Woods, Organon Ltd, whilst the $\left[6,7-{ }^{3} \mathrm{H}_{2}\right]$ oestradiol-17 $\alpha$ was generously prepared by Syntex Pharmaceuticals Ltd (Dr Walter Hafferl), California, to whom we extend our gratitude.

We are pleased to acknowledge the helpful advice of Professor K. Griffiths and the facilities made available to us at the Dr Len West Research Laboratories, Sully Hospital, Glamorgan. 


\section{REFERENCES}

Brinsfield, T. H. (1968) Relationship of endocrine state to spontaneous motility of sheep myometrium in vitro. F. Anim. Sci. 27, 439.

Brooks, S. C., Leithauser, G., De Loecher, W. C. \& De Wever, F. (1969) In vitro stimulation of protein synthesis in uterine microsomal supernatant by estrone sulphate. Endocrinology, 84, 901.

Burstein, S. \& Lieberman, S. (1958) Hydrolysis of ketosteroid hydrogen sulfates by solvolysis procedures. 7. biol. Chem. 233, 331 .

Csapo, A. I. (1961) Defence mechanism of pregnancy. In Progesterone and the Defence Mechanism of Pregnancy. Ciba Fdn. Study Grp. No. 9, p. 3. Eds. G. E. W. Wolstenholme and M. P. Cameron. Churchill, London.

Csapo, A. I. (1969) The four direct regulatory factors of myometrial function. In Progesterone: its Regulatatory Effect on the Myometrium. Ciba Fdn. Study Grp. No. 34, 13. Eds. G. E. W. Wolstenholme and J. Knight. Churchill, London.

Deanesty, R. (1966) The endocrinology of pregnancy and foetal life. In Marshall's Physiology of Reproduction, 3rd edn. Vol. 3, p. 891. Ed. A. S. Parkes. Longmans Green, London.

Fitzpatrick, R. J. (1960) The reactivity of the ruminant uterus to posterior pituitary hormones. J. comp. Path. 70, 36.

Hamilton, T. H. (1971) Steroid hormones, ribonucleic acid synthesis and transport, and the regulation of cytoplasmic translation. In The Biochemistry of Steroid Hormone Action. Ed. R. M. S. Smellie. Academic Press, New York.

Harvey, G., Pierrepoint, G. G., Anderson, A. B. M., Turnbuli, A. G. \& Griffiths, K. (1972) A time-based study of the in vitro metabolism of $\left[4-{ }^{14} \mathrm{C}\right]$ androstenedione and $\left[1,2-{ }^{3} \mathrm{H}_{2}\right]$ epitestosterone by sheep placental tissue. Biol. Reprod. 7, 15.

Knifton, A. (1967) The effects of posterior pituitary hormones on isometric tension and isotonic shortening of the pig myometrium. F. Pharm. Pharmac. 19, 439.

Kuriyama, H. (1961) Recent studies on the electrophysiology of the uterus. In Progesterone and the Defence Mechanism of Pregnancy. Ciba Fdn. Study Grp. No. 9, p 51. Eds. G. E. W. Wolstenholme and M. P. Cameron. Churchill, London.

Needham, D. M. \& Cawkwell, J. M. (1957) The protein composition and nucleic acid content of the rat uterus in different states. Biochem. 7. 65, 540 .

Pierrepoint, G. G., Anderson, A. B. M., Griffiths, K. \& Turnbull, A. C. (1970a) Investigations into the metabolism in vitro of $\mathrm{C}_{19}$-steroids by the sheep placenta. Biochem. $7.118,901$.

Pierrepoint, G. G., Anderson, A. B. M., Griffiths, K. \& Turndull, A. C. (1970b) Some aspects of steroid metabolism in the sheep placenta. 7. Endocr. 47, ii.

Pierrepoint, C. G., Anderson, A. B. M., Harvey, G., Turnbull, A. C. \& Griffiths, K. (1972) The conversion in vitro of $\mathrm{C}_{19}$-steroids to oestrogen sulphates by the sheep placenta. $\mathcal{F}$. Endocr. 50, 537.

Pierrepoint, C. G., Anderson, A. B. M., Turnbull, A. C. \& Griffiths, K. (1973) In vivo and in vitro studies of steroid metabolism by the sheep placenta. In The Endocrinology of Pregnancy and Parturition. Experimental Studies in the Sheep. Ed. G. G. Pierrepoint. Alpha Omega Alpha Publishing Co., Cardiff.

Rossier, G. \& Pierrepornt, C. G. (1974) The in vitro metabolism of $\mathrm{C}_{21}$ - and $\mathrm{C}_{19}$-steroids by pregnant sheep myometrium. 7. Reprod. Fert. 36, 169.

Rossier, G., Pierrepoint, G. G., Wilson, D. \& Griffiths, K. (1972) Steroid hormone-binding in sheep pregnancy myometrium. 7 . Reprod. Fert. 31, 502.

Ryan, K. J. (1969) Theoretical basis for endocrine control of gestation-a comparative approach. In The Foeto-placental Unit. Excerpta Med. Congr. Ser. No. 183, p. 120.

Schofiedd, B. M. (1964) Hormonal control of myometrial contraction. In Pharmacology of Smooth Muscle, Vol. 6. Ed. E. Bulbring. Pergamon Press, Oxford.

Segal, S. J. \& Scher, W. (1967) Estrogens, nucleic acids, and protein synthesis in uterine metabolism. In Cellular Biology of the Uterus, p. 114. Ed. R. M. Wynn. Meredith Publishing Co., New York.

SweAt, M. L., Bryson, M. J. \& Young, R. B. (1967) Metabolism of $17 \beta$-estradiol and estrone by human proliferative endometrium and myometrium. Endocrinology, 81, 167.

WrchmanN, K. (1967) On the metabolism and subcellular distribution of progesterone in the myometrium of the pregnant rat. Acta endocr., Copenh., Suppl. 116.

WrEst, W. G. (1963) In vitro metabolism of progesterone and 20 $\alpha$-hydroxy-pregn-4-en-3-one by tissues of the female rat. Endocrinology, 73, 310.

Williams-Ashman, H. G. \& Reddi, A. H. (1971) Actions of vertebrate sex hormones. A. Rev. Physiol. 33, 31 . 